University of Nebraska - Lincoln

DigitalCommons@University of Nebraska - Lincoln

\title{
Masculinities in Conflict: Representations of the Other in Narrative during the Spanish Civil War
}

Iker González-Allende

University of Nebraska-Lincoln, igonzalezallende2@unl.edu

Follow this and additional works at: https://digitalcommons.unl.edu/modlangspanish

Part of the Modern Languages Commons

González-Allende, Iker, "Masculinities in Conflict: Representations of the Other in Narrative during the Spanish Civil War" (2010). Spanish Language and Literature. 46.

https://digitalcommons.unl.edu/modlangspanish/46

This Article is brought to you for free and open access by the Modern Languages and Literatures, Department of at DigitalCommons@University of Nebraska - Lincoln. It has been accepted for inclusion in Spanish Language and Literature by an authorized administrator of DigitalCommons@University of Nebraska - Lincoln. 


\title{
Masculinities in Conflict: Representations of the Other in Narrative during the Spanish Civil War
}

\author{
Iker González-Allende \\ University of Nebraska-Lincoln, USA
}

\begin{abstract}
In this article, I analyze the representation of the Other in three texts that were published during the Spanish Civil War: El infierno azul (1938?), by Republican Isidro R. Mendieta, and two closely related works by Falangist Jacinto Miquelarena: Cómo fui ejecutado en Madrid (1937) and El otro mundo: La vida en las embajadas de Madrid (1938). Although these texts adhere to different political ideologies and are stylistically very divergent, they are similar in their constant criticisms of the enemy. Furthermore, both Republicans and rebels tend to depict the enemy as possessing an inadequate masculinity. He is described, on one hand, as a beast or an animal, unable to control his instincts, and, on the other hand, as an unmanly and effeminate coward. Thus, for the construction of the nation, the Other presents an inappropriate masculinity, which is either excessive and uncontainable, or insufficient. Therefore, national ideologies seem to propose a normative masculinity that is located in an ambiguous middle ground: a masculinity that is able to control animal instincts yet capable of heroic acts.
\end{abstract}

Keywords:Spanish Civil War, Jacinto Miquelarena, Isidro Mendieta, masculinities, enemy, the Other

Alors c'est ça l'enfer. Je n'aurais jamais cru...

Vous vous rappelez: le soufre, le bûcher, le gril ...

Ah! quelle plaisanterie. Pas besoin de gril, l'enfer, c'est les Autres.

Jean Paul Sartre, Huis clos (1944)

Para amar la libertad de la Patria,

es preciso odiar a muerte a quien la esclaviza.

Sabino Arana (1895)

$\mathrm{N}^{a}$ ational identity usually is configured in opposition to the Other, which creates a dichotomy between "us" and "them," that is, between what is considered to belong legitimately to the nation and what is seen as a foreign and threatening element. As 
Michael Billig points out, the national community can be imagined only when foreign communities also are imagined (1995: 79). Of course, there are less negative views of nationalism. For instance, contemporary philosopher Xavier Rubert de Ventós believes that nationalism's opposition between "us" and "them" is not always fixed because nationalisms are in a constant relationship of co-dependence among each other. De Ventós calls this situation "a play of crossed narcissisms" (1999: 141). Nevertheless, this phenomenon of harmonious coexistence does not occur when national ideologies are exclusionary and monolithic, in other words, when specific national groups see themselves as "the" vehicle of patriotism and nationality and, therefore, believe they do not need to exchange ideas with other political parties. This has been the case of Spanish nationalism in relation to its own internal others (Jews, Muslims), but especially in relation to the "peripheral" nationalisms, thus causing fraught and conflicting situations (Delgado, 2002: 212). In such circumstances the national "us" becomes a "no" to others; in Spanish, "nosotros" becomes "no-a-otros" (De Ventós, 1999: 31).

During an armed conflict, nationalism's ultimate goal is the physical and symbolic elimination of the Other and, with it, the reaffirmation of a specific view of the nation and the state. The enemy epitomizes the antitype, that is, all the opposite values that society defends. The Other symbolizes depravity and contamination that put in danger the essence of the nation; hence, the armed battle is necessary to unify the nation and maintain or recover its purity. When the country is facing a civil war, the situation becomes more complicated, since the enemy is within one's frontiers, among us. For this reason, it is essential to identify this enemy with the foreigner, in order to label him a traitor to the nation and to ameliorate any regret for killing him. This was the case of the 1936-1939 Spanish Civil War, which broke out as a consequence of the exclusive and irreconcilable conceptions that Republicans and rebels had of the nation and/or the state - of what Spain, Euskadi, or Catalonia were.

In this article, I will analyze the representation of the Other in three texts that were published during the Spanish Civil War: El infierno azul (1938?), by Republican Isidro R. Mendieta, and two closely related works by Falangist Jacinto Miquelarena: Cómo fui ejecutado en Madrid (1937) and El otro mundo: La vida en las embajadas de Madrid (1938). Although these texts adhere to different political ideologies and are stylistically very divergent, they are similar in their constant criticisms of the enemy. Unlike other works or artistic representations during the Spanish Civil War that attacked the internal enemy or the camouflaged spy - for example, Ramón Puyol's famous posters - the enemy here is not hidden or lurking underneath the surface, but rather clearly differentiated and external. ${ }^{1}$

While the nation tends to be symbolized as a woman in national ideologies, the Other is usually portrayed as a male who threatens the motherland. In this essay my aim is to examine the various representations of the enemy's masculinity and their connection with specific views of the nation. Both Republicans and rebels tend to depict the enemy as possessing an inadequate masculinity. He is described, on the one hand, as a beast or an animal, unable to control his instincts, and, on the other hand, as an unmanly and effeminate coward. Joane Nagel explains that national discourses during wartime tend to construct the enemy as possessing this contradictory masculinity: "Accounts of many

1. Four of Puyol's artistic works appear in the volume of Spanish Civil War posters edited by John Tisa: “El pesimista," "El acaparador," "El rumor," and "El izquierdista" (1979: 100-01, 108-09). 
wars and nationalist conflicts include portrayals of enemy men either as sexual demons, bent on raping nationalist women, or as sexual eunuchs, incapable of manly virility" (1998: 257). Even in times of peace, some national discourses use this paradox when describing the enemy. For example, at the end of the nineteenth century Sabino Arana, the founder of Basque nationalism, referred to Spain as "pueblo a la vez afeminado y embrutecido" (2001: 95). Thus, for the construction of the nation, the Other presents an inappropriate masculinity, which is either excessive and uncontainable, or insufficient. Therefore, national ideologies propose a normative masculinity that is located in an ambiguous middle ground: a masculinity that is able to control animal instincts yet capable of heroic acts.

Isidro R. Mendieta and Jacinto Miquelarena played a politically active role during the Spanish Civil War. The former, however, presents an obscure biographical case. His name appears most often as the translator of books from Russian into Spanish - he probably went into exile in the USSR - and as the author of several works about socialist themes. On the other hand, Jacinto Miquelarena (b. Bilbao, 1891; d. Paris, 1962) belonged to what Julio Rodríguez-Puértolas called "the literary court of Primo de Rivera," referring to the writers who were friends of the founder of the Falange, the Spanish version of fascism (1986: 106). Miquelarena was a journalist, traveler, director of the sports newspaper Excelsior, and editor of $A B C$ (Amézaga, 1987: 366). During the Spanish Civil War, he directed several programs on the National Radio and also wrote two other works: Unificación (1937) and Cuentos de humor (1939).

The narratives by Mendieta and Miquelarena are different regarding style and structure. El infierno azul, by Mendieta, tells the story of Luis Rosado, who at the beginning of the novel forms part of a Republican troop and faces the rebels and stop their progress towards Madrid. He is arrested and imprisoned, and when he is about to be executed a Francoist second lieutenant who had been his friend recognizes Luis and saves him. Thereupon, Luis pretends to support the rebels and gets a job as the chauffeur for a Francoist captain. At the end, he runs away from the rebel area and comes back to the Republican territory. Luis is a mere excuse for the author to present the savagery of the enemy, and for this reason the surprised reader sees how he appears and disappears in the narrative without advance warning.

Cómo fui ejecutado en Madrid, by Miquelarena, consists of a collection of short articles in which the author describes his impressions of Republican Madrid during the war. The work opens with an introduction in which Miquelarena tells the different versions that people gave about his fake shooting. Obviously, the author is still alive, but he regrets not having died like a hero. The rest of the book is divided into seven parts, in which Miquelarena criticizes, often in a humorous way, what he considers Republicans' atrocities: propaganda, murders, and tortures in jails.

In El otro mundo, Miquelarena writes his memoir of his seven-month stay in the Argentinian embassy in Madrid during the war and his attempts to escape from the Republicans, who wanted to kill him. The book is written in the first person and is divided into twenty-six untitled, short chapters. First, Miquelarena remembers several aspects of Republican Madrid before the outbreak of the war. For example, he writes about the creation of the Falange's hymn and the Falangist intellectual gathering called "La Ballena Alegre." Secondly, he relates the daily life in the embassy with other Francoist refugees. Finally, the author tells how he leaves the embassy with other people, boards a ship in Alicante, and achieves his freedom. 
These two works by Miquelarena were written almost at the same time and, although the former is a collection of political and social essays and the latter is the author's memoir, both of them contain autobiographical and propagandistic elements. There are even some paragraphs and ideas that are repeated in the two works, for instance, when the author discusses the Republican press.

\section{The Monstrous Other}

Both Mendieta and Miquelarena characterize the space occupied by the enemy as infernal. As the title of Mendieta's novel makes apparent, the enemy's territory is described as a locus of suffering and hardships, as the opposite of what happens on the other side. José Antonio Pérez Bowie believes that this kind of narrative in which the author seeks to degrade the enemy prevailed on the rebel side more than on the Republican side (2002: 4243). To support this idea, he gives several examples of titles of Francoist novels published during the war that show an obvious Manichean interpretation of the conflict and a harsh criticism of the enemy: for instance, La agonía de Madrid, by Adelardo Fernández Arias, or ¿Queman, roban y asesinan en tu nombre!, by J. García Morales. It is true that there were more of these novels on the rebel side, but, as Mendieta's work shows, Republican authors used a similar rhetoric to vilify the enemy.

In armed conflicts, national ideologies label the enemy as an outsider to the true nation and tend to identify him with the foreigner or the racial Other, who also is usually associated with an excess of sexuality or hypermasculinity. ${ }^{2}$ In civil wars, the citizen of the same nation who maintains a different ideology is seen as a traitor to his own country when he receives help from another nation. Moreover, each side believes that the opposite faction has sold his country to foreign nations that will take possession of everything. In this sense, Alberto Reig Tapia thinks that the Spanish Civil War consisted, in fact, of a "negative war," that is, a fight between anti-fascists and anti-Marxists (1999: 77). Thus, Republicans believed that the rebels were fascists led by Hitler and Mussolini, while the rebels considered that all of the Republicans were communists controlled by Russia (Álvarez Junco, 2001: 145; García de Cortázar, 2003: 300). Both Republicans and rebels assumed that they represented the "real" Spain and that the victory of the other side would imply that the country fell into the hands of foreign troops. For this reason, the two sides compared their situation with the so-called Independence War, that is, the 1808 war between Spaniards and Napoleon's French troops that invaded Spain. Republican leader Dolores Ibárruri herself stated that the war was not a civil war anymore, but an independence war in defense "de nuestra España, de la España popular [que] se ha forjado indomable y grandiosa a través de los siglos" (quoted in Juliá, 1999: 24).

In a similar way, for Basque and Catalan nationalists, the rebels represented the foreigners who wanted to take possession of their homeland, Euskadi or Catalonia. ${ }^{3}$

2. For instance, Christina Jarvis points out that, during the Second World War, in the United States black men were connected with the Other and with a threatening sexuality, while white men were considered the normative representation of the country (2004: 120).

3. Basque and Catalan nationalists supported the Republic because it allowed them to have a statute of autonomy. In the case of Basque nationalism, due to its Catholicism, the divergence with the Republic was a constant during the war. 
Nevertheless, the rebels appealed to the rhetoric of foreigner invasion more constantly than the Republicans. It must be remembered that they called themselves "nationals" or "nationalists" during and after the war, thus locating the Republicans in the non-national position. Indeed, as the rebels defended the ideas of a homogenized, unified, "eternal" Spain and the recovery of its imperial past, they firmly established that they were the only ones fighting for Spain, and therefore labelled the other side as the "anti-Spain."

This association of the enemy with the racial Other or the foreigner appears very clearly in the works I am analyzing. Mendieta insists on the idea that foreign nations control Spain because of Franco. When he writes about the Moroccan troops that helped the rebels, he identifies them with the racial Other, in this case Arab. He especially criticizes their desire to accrue riches: "Cada vez que avanzaban, cada vez que caía un pueblo en su poder, ya se sabía: los moros aparecían con sortijas, con turbantes nuevos, con gallinas bajo el brazo" (1938: 12). ${ }^{4}$ During the war, "Moors" personified people's collective terror and reminded Republicans of the 711 invasion of the Peninsula (Flesler, 2001: 79). ${ }^{5}$ The depiction of Moroccans as uncontrollable and savage is similar to the European descriptions of the backward oriental Other that Edward W. Said analyses. Even the rebels, for whom the Arab mercenaries fought, connected the "Moor" soldiers with an excessive sexuality. For example, in his speeches on the radio, the infamous general Queipo de Llano delighted in telling crude stories about Moroccans' sexual prowess in order to spread panic among Republicans (Madariaga, 2002: 315). ${ }^{6}$

In view of the foreign domination of Spain, Mendieta wonders how it is possible that the people who claim to be fighting for the unity of Spain are handing the country over to foreigners: "¿Qué Patria puede ser la que permite que sus hijos sean asesinados por extranjeros? ¿Qué Caudillo el que abre las puertas de su Patria a los Ejércitos del fascismo internacional para que conquisten nuestras riquezas, violen a nuestras hermanas, a nuestras mujeres, a nuestras hijas y asesinen a todo lo que de avanzado y progresivo hay en nuestra Patria?" (1938: 21-22). In this passage, the Other is constructed as a violent sexual predator while, from a heteronormative perspective, the woman stands as a metaphor for the nation.

Miquelarena mocks the Republican association between Franco, Hitler, and Mussolini when he says that the Republicans call them "fachistas." The author emphasizes the incorrect pronunciation of the word fascista in order for the reader to focus not on the help that Francoists received from foreign armies, but on the lack of formal education of the

4. Abdelmajid Benjelloun believes that Moroccans also enrolled in Franco's army to kill Spaniards and thus take revenge for the historical humiliations they had suffered at the hands of the Spanish government (quoted in Sánchez Ruano, 2004: 247). However, the rebel side created a discourse of fraternity between Francoists and Muslims based on the idea that both groups were fighting in favor of religion and against the communist atheism represented by the Republicans (Madariaga, 2002: 351). The rebels even elaborated a new representation of the "friendly Moor," based on the consideration of Morocco as a backward extension of Spain (Núñez-Seixas, 2006: 262).

5. Despite the fact that approximately seventy thousand Muslims fought in the rebel army, it has to be remembered that in the Republican militias there were also one thousand Muslims (Sánchez Ruano, 2004: 277). Nevertheless, the Muslims who supported the Republic were volunteers and most of them came from Maghreb (Sánchez Ruano, 2004: 257).

6. The film Libertarias (1995), by Vicente Aranda, is a recent representation of this vision of the "Moors" as hypersexual: at the end of the movie the Republican militiawomen are raped and killed by Moroccan troops. 
people who supported the Republic. In contrast, Miquelarena believes that the Republic has handed Spain over to Russia. For instance, he writes that the city of Valencia behaves like Russia's doorwoman (1937: 79). This comment is meant to be degrading in terms of power: the Republican city is not only feminized, but also marked as belonging to the lower social classes.

When national ideologies depict the enemy during wartime, they invariably describe him negatively, both in the physical appearance and in regard to his morals and intellectual abilities. As George Mosse explains, the outsider symbolizes physical and moral disorder (1996: 57). For Mosse, the enemy's physical ugliness is a representation of his lust, cowardice, nervousness, and lack of control over his instincts (1996: 59). León Pomer points out the same idea: ignorance and physical deformity are often associated when depicting the enemy (2005: 85). Mendieta does not mention the enemy's physical appearance or intellectual ability, but, on the contrary, Miquelarena describes the enemy in great detail.

Regarding the enemy's morals, Miquelarena gives as example of depravity his constant use of blasphemies, which he clearly relates to his low social status. By contrast, according to the author, all the right-wing refugees in the embassy maintained good manners, such as not slurping their soup, or wiping their mouth with a piece of paper as a napkin after having eaten (1938: 167-68). Miquelarena pejoratively describes the enemy in the most thorough way in the section entitled "Galería de monstruos" in Cómo fui ejecutado en Madrid. The term "monstruos" itself refers to the Other's cruelty and lack of humanity and rationality. For instance, the author mocks and dismisses the intellectual ability of the president of the Basque Government, José Antonio de Aguirre. In his words, "es uno de los hombres mejor preparados para suministrar mayor número de idioteces en menor cantidad de tiempo" (1937: 152). As shown in this quotation, the author's rhetorical strategy of using humor consists of including in the same sentence a positive clause ("es uno de los hombres mejor preparados"), followed by a negative phrase that cancels the positive statement ("para suministrar mayor número de idioteces en menor cantidad de tiempo"). This particular use of wit to discredit the enemy is consistent with the author's "aristocratic" perspective: he looks down on the object of his criticism and reduces him to mere material for laughs. ${ }^{7}$

When Miquelarena describes the enemy's physical appearance, he depicts the Other as overweight in order to discredit him. For example, he portrays the son of the socialist minister Indalecio Prieto as "redondo como su padre" (1937: 149). Further on, when the author mentions Republican writer José Bergamín, he calls him "el excremental" (1937: 175). This adjective connects the representation of the enemy during wartime with Julia Kristeva's idea of abjection. As Judith Butler explains, through the excreting function, the inner becomes outer and the differentiation between both is accomplished. In her words, "this is the mode by which Others become shit" (1990: 134). In this way, when Miquelarena degrades the enemy through scatological imagery, he is turning Spanish citizens not only into disgusting foreigners, but also into fecal matter, something to be disposed of. The enemy becomes the excrement that Spain's body has to expel in order to function properly.

7. Mónica Carbajosa points out that the humor that Miquelarena uses in his works consists of short and witty sentences, with the influence of Ramón Gómez de la Serna and Julio Camba (2003: 19). 
Another characteristic of the enemy that Miquelarena mentions on multiple occasions is his lack of hygiene, especially men's unshaven look. In general, Miquelarena identifies the enemy with physical dirtiness, which, for him, means at the same time stagnancy of ideas. In contrast, the author underlines his own personal hygiene. For instance, he relates that he asked for a mirror in order to shave his three-day beard and that he created a public shower in the embassy in order for the refugees to wash themselves. In this way, Miquelarena wants to convey the idea that Francoist physical cleanliness implies moral cleanliness, an idea that the Franco regime would later reinforce, equating the squalor and deplorable physical conditions of the surviving Republicans with overall weakness and lack of decency.

Animalization is the most hyperbolic figure that Mendieta and Miquelarena use to criticize the enemy. As Enrique Gil Calvo points out in his analysis of masculine archetypes, the others are usually portrayed as monsters that "se comportan con la maldad despiadada de una bestia inhumana" (2006: 289). During wartime, national ideologies try to dehumanize or animalize the Other, considering him a beast that needs to be eliminated in order to restore the nation to civilization and normality. This conception allows national soldiers to feel less guilty when it is time to kill the enemy, since they will not be killing fellow human beings, but animals. Thus, war is considered a fight between one's civilization and the Other's savagery. There are many examples of the animalization of the enemy during wartime. For instance, Paul Fussell indicates that, during the Second World War, Americans used to describe Japanese people as bestial apes ("Japes"), jackals or wildcats (1989: 116-17). In the Spanish Civil War, in his 7 fábulas de Samaniego adaptadas a la actualidad española, Antonio Joaquín Robles Soler identified the rebels with several animals: for instance, Queipo de Llano is a raven, fascists are flies, or a Francoist general is a vixen (Chicote, 2006: 160-61).

Both Mendieta and Miquelarena fall into contradiction regarding animalization: even though they resent the way they are animalized by the other side, they also use animal metaphors to depict the enemy. Thus, on one hand, Mendieta provides as an example of the enemy's cruelty a Francoist commander who calls the Republicans "perros marxistas a los que hay que exterminar" (1938: 13). However, on the other hand, Mendieta himself animalizes the rebels, calling them "hienas" (1938: 6), "fieras" (1938: 16) or "buitres" (1938: 21). These words depict the rebels as brutal and the Republicans as their innocent victims.

Miquelarena offers many more examples of animal metaphors than Mendieta. For instance, he writes that the members of the Republican militia "huían como ratas" (1937: 40), or were "linces" to steal money (1937: 48). He also calls them "ganado" (1937: 112), "fauna" (1937: 141), “asno" (1937: 145), “foca" (1937: 148), “cerdo" (1937: 149), and "hipopótamo" (1937: 179). Like Mendieta, Miquelarena chooses animals with negative connotations. However, while Mendieta selects animals widely known for their ferocity and wildness, Miquelarena uses those animals linked to physical ugliness, clumsiness, or lack of intelligence.

During the Spanish Civil War both sides believed that detailed accounts of the enemy's atrocities were needed in order to fully exemplify his bestiality. The description of the enemy's outrages and violent actions in many books and posters published or issued during the war years anticipate what will be called "tremendismo" in the Spanish narrative of the 1940s, but it also harkens back to the dark universe 
of the "esperpento." 8 One of the enemy's atrocities that Mendieta and Miquelarena emphasize is the mistreatment of prisoners. This appears clearly in the image of the cover of El infierno azul (Figure 1), which is signed with the initials "A.T.," probably the Republican artist Aníbal Tejada, who worked for the Altavoz del Frente (Bozal, 1995: 613). In the illustration, the two raised handcuffed hands symbolize the lack of freedom that, according to the artist, the rebel faction wants to impose in Spain. The hands also represent the workers, and, in general, the whole of humanity that is not allowed to have free will. The expression "terror fascista" that appears under the hands makes obvious its political message; in fact, the novel belongs to the collection with that title.

Mendieta's work includes three illustrations about specific moments of Luis's imprisonment under the rebels' control. The most significant one is Figure 2, where the common practice of indiscriminate shooting exemplifies the Other's cruelty. In the image, two Francoist soldiers appear with rifles in their hands, while Luis is standing in front of a wall, waiting to be executed. The illustrator seems to take delight in drawing male body shapes, as shown in the main character's bare muscular chest, which symbolizes the nation's strength. At Luis's feet, there are three already dead Republicans to demonstrate the great number of murders committed by the rebels. Mendieta also underlines the pleasure the rebels obtained from the tortures of prisoners: "pisotearon cuerpos y más cuerpos deleitándose con los gritos de dolor y de angustia de sus víctimas" (1938: 9).

Miquelarena also discusses the living conditions in the enemy's prisons and gives similar information to the one offered by Mendieta. Furthermore, he dedicates a chapter to the "checas," that is, prisons that were not controlled by the Republican government, but by different groups of militias. He also writes in detail about socialist Agapito García Atadell, who, in his opinion, "mataba por robar, pero también por sadismo" (1937: 45). Like Mendieta, Miquelarena wants the reader to believe that the enemy enjoyed murdering people. Another killing procedure that this author explains is "el paseo," which was a form of torture wherein a person was arrested in his house and walked to a place outside the city to be executed. In El otro mundo, Miquelarena, significantly, describes the general atmosphere of the city with the sentence "Madrid chorreaba sangre" (1938: 98).

From Miquelarena's point of view, the instigators of the atrocities in Madrid were not only the militias or the Republican soldiers, but also the masses or the common people. This is something that differentiates Miquelarena from Mendieta, since for the latter, the Other is never associated with the common people, but with insurgent soldiers and their foreign allies. Moreover, Mendieta refers to the Other only as specifically male. In contrast, when Miquelarena mentions the masses, he feminizes them, following a rhetorical tradition that harkens back to the nineteenth century. The author thinks that the masses are capable of monstrosities as terrible as those committed by the soldiers. For example, he writes that "la romería de gentes - mujeres de manera especial - [ . . ] iban a contemplar los cadáveres, a profanarlos con insultos y puntapiés" (1937: 28, my emphasis). In this quotation, the author

8. As is well known, the term esperpento was created by Ramón del Valle Inclán in his drama Luces de bohemia (1924) to designate an aesthetics based on the deformation of reality, the degradation and animalization of the characters, the emphasis on grotesque techniques, the use of verbal violence and contrasts, and the omnipresence of death. The main objective of the esperpento is to criticize Spanish society. In Spanish literature and art, the esperpento also can be found in the works by Francisco de Quevedo, Francisco de Goya, or in the picaresque novel. 


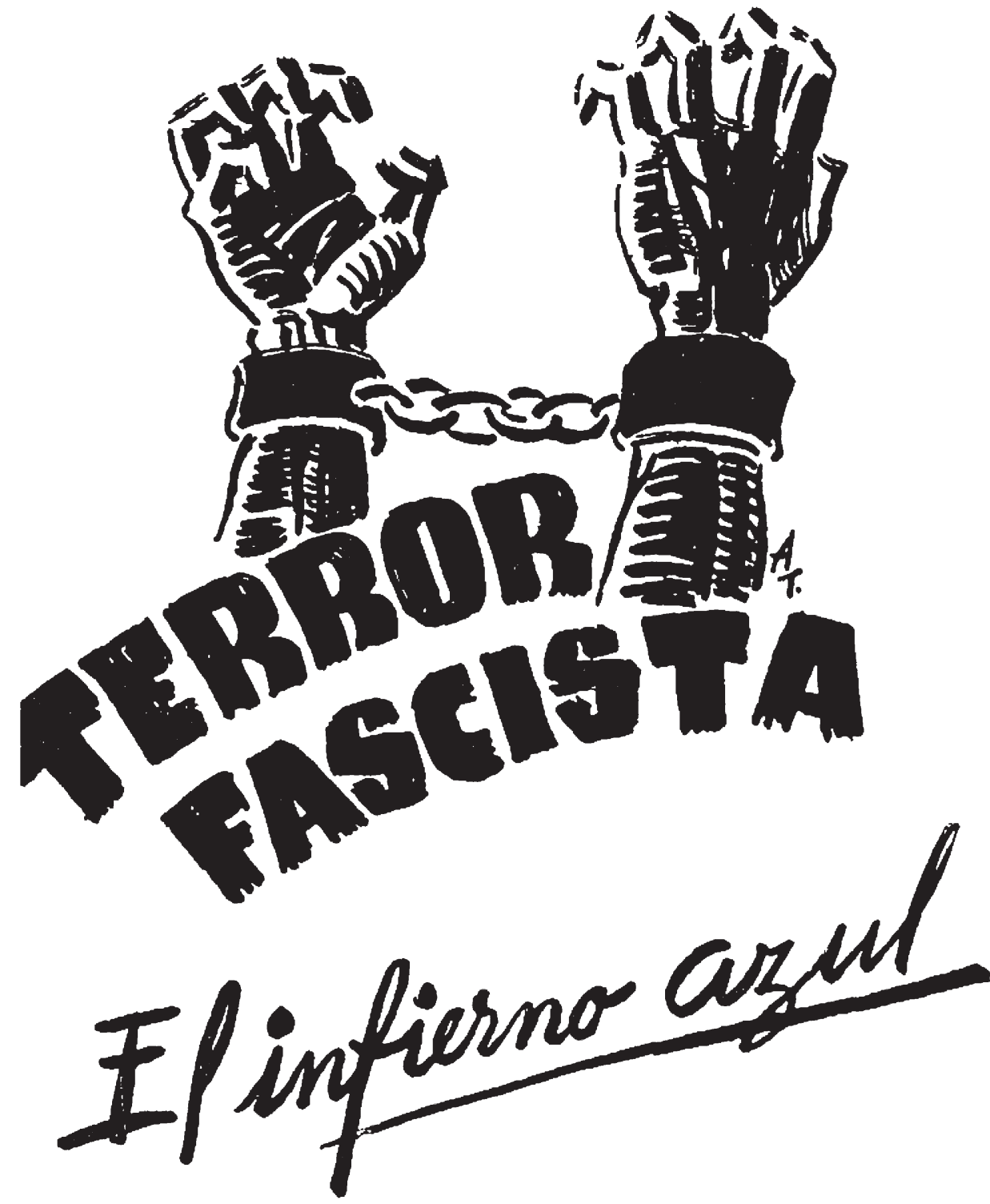

\section{Isidro R. Mendiefa}

Figure 1. Cover of El infierno azul (1938?), by Isidro R. Mendieta.

refers directly to women as harpies full of rancor and instigators of riots. This proves, as Tamar Mayer explains, that national ideologies tend to consider the enemy's women as amoral and impure (2000: 10). 


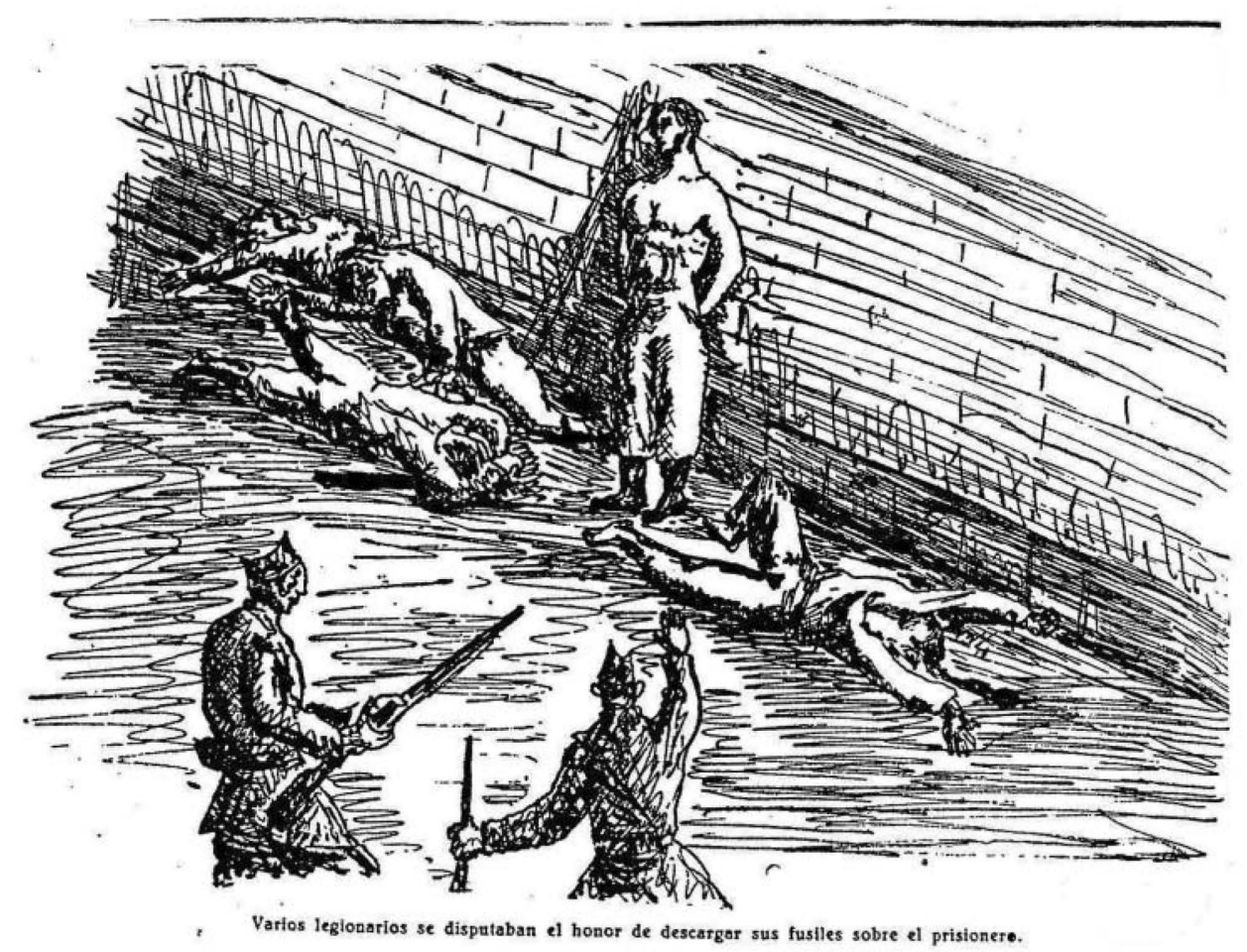

Figure 2. Illustration included in El infi erno azul (1938?), by Isidro R. Mendieta.

Francoist psychiatrist Antonio Vallejo Nágera even wrote during the war that the cruelty of Republican women was more sadistic than that of men due to their "debilidad del equilibrio mental, la menor resistencia a las influencias ambientales [...] y la tendencia a la impulsividad" (1939: 222). In this misogynist comment, it is clear that, for the rebel side, women also represented the Other, which may be explained as a consequence of the longstanding historical connection between women and mystery. In this way, when Miquelarena criticizes the masses, he displays not only his fear of the low social classes, but also his fear of women.

At the same time, it is remarkable how often these works focus on the enemy's pleasure in inflicting violence upon women and children. In fact, this is one of the most repeated topics in war narratives, since it presents the enemy as uncompassionate with the weakest ones. During wartime, national ideologies construct the enemy as the biggest threat to their women's sexual purity. ${ }^{9}$ In Julie Mostov's words, "the Other's men are seen collectively as sexual aggressors" (2000: 92). Unfortunately, in reality, women become in many cases war victims because soldiers believe that this is the best way to humiliate the men of the other side. Moreover, as women are identified with the essence of the nation, an attack against women also implies an attack against the nation. From this point of

9. Even in some romances during the war, the heroism of militiawomen is lessened when presenting them as women in danger of being raped. This happens in a romance about Lidia Odena, in which she kills herself in order to avoid suffering this brutal attack (Linhard, 2005: 127). 
view, the aim of mass rapes is not for the soldiers to obtain sexual pleasure, but to invade the Other's territory, property, and space. On the other hand, Rhonda Copelon points out that women are the targets of the enemy army not only because women are thought to belong to the nation's men, but also because women become indispensable for the nation's civil life (1998: 71).

Mendieta discusses in great detail the violence inflicted upon Republican women. I have already mentioned his comments about the rapes by foreign troops, but he gives more examples of mechanisms of coercion upon women, such as shaving their heads. With this practice, the rebels tried to leave a mark on women's bodies in order to exert control over them and desexualize them - since long hair was considered a specifically female sexual attribute. Francisco Moreno also points out that after the war Francoists used to make shaven-headed Republican women walk throughout the village streets as a means of labeling them as sub-human (1999: 366). ${ }^{10}$ Despite the humiliations the Republican women had to bear, Mendieta underlines their courage: "Mataron a mi padre y a mi hermano. Mi novio lo tenéis en un campo de concentración. No os temo. Ya las pagaréis todas juntas. Esto que llevo en la cabeza es honra" (1938: 29). In this quotation, the woman reverses the aim of the rebels' punishment: her shaved head becomes for her a sign of pride and resistance.

Miquelarena does not explain in detail the Francoist women's situation in the Republican area. Nevertheless, he points out that in the Republican prisons there were 1600 Francoist women who had to suffer numerous tortures, such as witnessing male prisoners' executions (1937: 42).

\section{The Effeminate Other}

National ideologies represent the enemy not only as a beast or an animal, but also as cowardly and effeminate, that is, as possessing an insufficient masculinity. Nationalisms believe that femininity in men is a fault that prevents the nation from growing strong and powerful. In modern times, normative masculinity is based in heterosexuality, virility, and physical strength; in a military context, masculinity also includes other values such as chivalry, selflessness, and sacrificing one's life for the nation. The coward, however, is considered a weak and effeminate man, not suitable for the nation's future, untrustworthy, and unable to govern a country. In fact, Jean Bethke Elshtain points out that the best way to insult the enemy is to call him "woman" (1987: 196). James McBride also thinks that the enemy's feminization becomes essential during wartime to maintain the patriarchal social order: "The enemy is woman because she is what men are not but fear they might become. Ritual victimization of the enemy as female confirms male identity" (quoted in VettelBecker, 2002: 87). Thus, national ideologies portray the enemy in stereotyped female terms, as an impure and threatening enigma. Moreover, war, like traditional masculinity, is based on the idea of the subjugation of the feminine.

Mendieta and Miquelarena give many examples of the enemy's cowardice in order to identify him with the feminine. For instance, Mendieta writes that the rebels' tanks run

10. In her novel La voz dormida (2002), Dulce Chacón relates in chilling detail this type of abuse against Republican women during the post-war period. Jesús Ferrero also has told a similar story in Las trece rosas (2003), which became a movie in 2007 under the direction of Emilio Martínez Lázaro. 
away in view of the Republicans' bravery. The fact that the rebels do not dare to face the Republicans, even though they have more arms at their disposal, makes them appear to be cowards. In addition, a soldier's duty is to die on the front, which grants him heroic status, but the rebels here behave in an opposite way. Therefore, the enemy is neither able to die heroically, nor is he strong enough to suffer martyrdom. Mendieta projects this image of effeminacy especially onto the Falangists, who, in his opinion, stayed in the rearguard in charge of prisons in order to conceal their cowardice (1938: 8). ${ }^{11}$ According to Xosé-Manoel Núñez-Seixas, on the Republican side it was also common to present the Italian troops that helped Franco as "unmanly" (2005: 54).

Miquelarena describes the enemy as cowardly and effeminate more consistently than Mendieta. He indicates that the Republican soldiers do not run away just to reload their guns and come back to fight, but to desert, steal, and travel abroad to personal safety. In Miquelarena's opinion, the fact that the Republican Government moves from Madrid to Valencia also exemplifies their fearfulness. Another trait of the enemy that Miquelarena likes to emphasize is his nervous condition and his inability to control stressful situations. For this reason, he calls Republican soldiers "schizophrenic" several times (1937: 95, 151). In this sense, it is relevant to remember that suffering from a nervous condition, or in an extreme case becoming hysterical, was considered typical of sick people, and in men it was (and perhaps still is) related to a lack of virility (Mosse, 1996: 83). At other times, the author clearly feminizes the enemy in a humorous, albeit cruel, way. For instance, he writes that when Republican writer José Bergamín was born, "nadie sabía si aquello era niño, niña o salmonete" (1937: 175). Miquelarena believes that effeminacy is incompatible with the bravery necessary during wartime and with the strong masculinity needed to construct the new nation.

In El otro mundo, Miquelarena's descriptions of the enemy are so hyperbolic that they can be considered grotesque. For example, when the Council of Ministers finds out about the military coup d'état, Miquelarena relates that all the ministers turned pale and went down the stairs hastily. Their identification with a group of women is obvious: "Su actitud, su gesto, su temblor, su alocamiento femenino, eran exactamente los del cobarde segundos antes de caer de rodillas y de pedir perdón" (1938: 34, my emphasis). Miquelarena gives other examples, such as militiamen "temblando como monas" because of the bombings (1938: 108), or Republican leaders who "temblaban como mujerzuelas y se escapaban como ratas" (1938: 140). The author clearly connects cowardice and debased femininity, an association that is not present in Mendieta and that will reappear in Francoist narrative during the post-war period.

Mendieta's and Miquelarena's view of weak masculinity is not exempt from contradictions. On one hand, both authors mock the enemy and present him as cowardly and effeminate, but on the other hand, the main characters in their works also choose not to fight for a long time, hide, and have double identities. Thus, their characters do not really fulfill the duties that society expects from men during an armed conflict. In Mendieta's novel, it is true that Luis Rosado fights on the front at the beginning, but soon after, he pretends to be a rebel and works as a chauffeur for a Francoist captain in order to escape imprisonment. Therefore, his behavior cannot be described as an example of bravery, but

11. George Orwell also writes in Homage to Catalonia that when he and the other Republican soldiers of his army were approaching the front line, they used to scream "Fascistas-maricones" (1938: 22). 
as a selfish action. The reader can also wonder why he spends so much time - thirteen months - camouflaged in the rebel area. The narrator does not explain this matter very clearly: “Otras veces había pensado ya en la fuga. No fue posible. Le faltó decisión. ¡Son tantos los riesgos!" (1938: 30, my emphasis). Judging by this comment, Luis was not brave enough to risk his life, although at the end of the work he finally runs away and returns to the Republican territory. This event on the last page of the novel is the author's last weak attempt at keeping the reader's sympathy for the hero, but in narrative terms it is too abrupt to be satisfactory.

In Miquelarena's case, the situation is more complicated because his works contain many autobiographical elements. The author endeavors to appear courageous, but he seldom accomplishes this. The pseudonym he uses to sign Cómo fui ejecutado en Madrid, "El Fugitivo," does not precisely connote bravery. Moreover, as he explains in the prologue, there were rumors in Madrid that the Republicans had executed him and that he stayed calm and loyal to Franco throughout his execution. The illustration on the cover of the book, created by Teodoro Delgado, represents this situation (Figure 3). ${ }^{12}$ The image depicts a well-dressed man, who probably belongs to the high social class, standing bravely in front of a shooting squad. The man's position, with his arms crossed and his body firm, as well as his defiant look, show his courageous acceptance of death. What is noteworthy here is that, in fact, Miquelarena was never in front of a shooting squad; on the contrary, he ran away from the enemy and spent seven months as a refugee in an embassy. The idea of dying like a hero or a martyr satisfies Miquelarena tremendously because he knows that in real life he would not be able to face death calmly. ${ }^{13}$

There are other occasions in which Miquelarena appears as lacking courage. In El otro mundo, when several militiamen come to the embassy to arrest him, he does not give himself up, although he knows that if the militiamen break into the embassy, the other refugees' lives are at risk. At the end, one of the embassy employees manages to persuade the militiamen to leave. Clearly, Miquelarena is thinking only of himself and of his own safety. In the last episode of his memoir, Miquelarena also demonstrates cowardice rather than heroism. When he leaves the embassy with other people and afterwards the entire group is arrested, he drinks alcohol in jail in order to feel stronger, something that a courageous man would not need. In short, these situations in which Miquelarena does not behave as a brave man are in contradiction with his continuous criticism of the enemy's cowardice. It is remarkable that these examples of the author's weakness appear in his own narrative, over which he has full control.

In their works, Mendieta and Miquelarena are intent on establishing clear and fixed boundaries between "us" and the Other, which is understandable given their context at the time of publication - in the midst of an armed civil conflict. Although these three

12. Teodoro Delgado (Toledo, 1907-1975) was an active member of the Francoist Propaganda Delegation. Before the war, he worked in Paris and Buenos Aires, collaborated in the newspaper $A B C$ and in the magazine Blanco y Negro, and illustrated editions of Don Quixote and the Bible (Carulla \& Carulla, 1997 : 67). During the war he painted the poster "España fue, es y será inmortal" (1937) and illustrated the dialogue Unificación, written by Miquelarena. Ángel Llorente considers him to be one of the most relevant illustrators on the rebel side (1995: 196).

13. Miquelarena was not the only writer on the rebel side who told about his own execution. For example, Rafael Sánchez Mazas, unlike Miquelarena, had to face a real execution, about which Javier Cercas wrote his famous novel Soldados de Salamina (2001). 


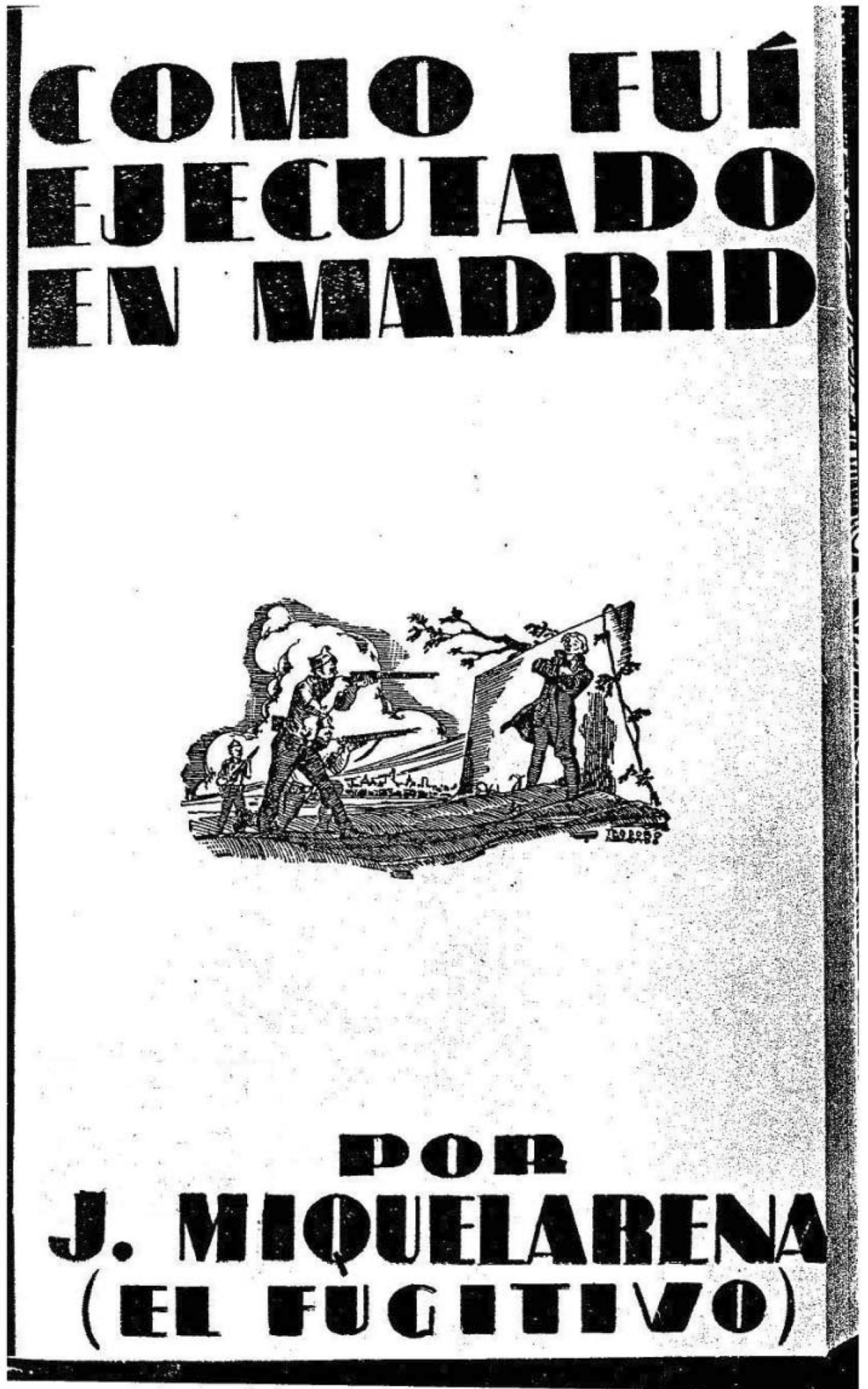

Figure 3. Cover of Cómo fui ejecutado en Madrid (1937), by Jacinto Miquelarena. 
works belong to different literary genres - short novel, collection of articles, and memoir respectively - they use Manichean propaganda in a very similar way. In fact, they are devoted exclusively to describing an infernal space conquered by the Other. Both authors identify the Other with a foreign nation or another race. Thus, the Spanish Civil War becomes in rhetorical terms a fight against the foreign invaders - Arabs, Italians, or Germans for Republicans; Russians for the rebels.

The authors present the enemy's masculinity in contradictory ways: he is either a hypersexual beast, or an effeminate coward. According to national ideologies, these two models of masculinity are extreme and inappropriate to construct a prosperous future for the nation. When the enemy is depicted as a beast, the war becomes a fight between one's civilization and the Other's savagery. On the other hand, when the enemy hides or runs away to avoid fighting, his masculinity is portrayed as insufficient and effeminate.

Although Mendieta and Miquelarena share similar rhetorical strategies in their depictions of the enemy, there are also some clear differences between them. For example, Mendieta is careful to mention that not all the people that supported the rebel side agreed with Francoist troops' behavior. Thus, two of the characters, a lieutenant and a nun, complain about the excessive number of murders committed by the rebels (1938: 13, 19). Although Mendieta may use these comments to convey the idea that the rebels were so violent that even people on their side criticized them, the author does not depict all enemies as monsters. There is, therefore, a willingness to concede that even "the enemy" is not a homogenous whole. Such subtlety cannot be found in the Falangist Miquelarena, whose detailed descriptions of a bestial and pathetic enemy leave no room for positive connotations whatsoever. Another important difference is that Mendieta tends to depict the enemy more often as a beast than as effeminate, while Miquelarena epitomizes the opposite emphasis. Furthermore, Mendieta identifies the Other with the rebel army, and not with the civilian population as a whole, while Miquelarena constructs the enemy as inseparable from the masses, thus uniting working class people, peasants, and women in the same despicable group.

After the war, the Francoist regime built its version of a "new Spain" by practically and symbolically erasing the Republican side from the national space. In a 1952 speech, the dictator is pleased that his regime has defeated again "las fuerzas seculares de la anti-España," thanks to the unity, calm and intelligence of the Spanish people (Franco, 2008). To the very end of the regime, those with a different vision of the nation were not allowed to express their ideas, dissent of any kind was considered treason and, moreover, incompatible with true Spanishness. Workers, the masses, women, homosexuals: they remained the anti-Spanish Other until the dictator's bitter end.

\section{Bibliography}

Álvarez Junco, J. 2001. Mater Dolorosa: La idea de España en el siglo XIX. Madrid: Taurus.

Amézaga, E. 1987. Autores vascos, vi. Algorta: Hilargi.

Arana, S. 2001. Páginas de Sabino Arana (Fundador del nacionalismo vasco). Madrid: Criterio.

Billig, M. 1995. Banal Nationalism. London: Sage.

Bozal, V. 1995. Arte del siglo XX en España: pintura y escultura, 1900-1939. Madrid: Espasa-Calpe.

Butler, J. 1990. Gender Trouble: Feminism and the Subversion of Identity. New York: Routledge.

Carbajosa, M. \& Carbajosa. P. 2003. La corte literaria de José Antonio: la primera generación cultural de la Falange. Barcelona: Crítica.

Carulla, J. \& Carulla, A. eds. 1997. La Guerra Civil en 2000 carteles, 2 vols. Barcelona: Postermil. 
Cercas, J. 2001. Soldados de Salamina. Barcelona: Tusquets.

Chacón, D. 2002. La voz dormida. Madrid: Alfaguara.

Chicote, G. B. 2006. Fábulas para la guerra: reformulación de literatura ejemplar en propaganda política. Olivar: Revista de Literatura y Cultura Españolas, 8: 153-63.

Copelon, R. 1998. Surfacing Gender: Reconceptualizing Crimes Against Women in Time of War. In: L.A. Lorentzen \& J. Turpin, eds. The Women War Reader. New York: New York University Press, pp. 63-79.

De Ventós, X. R. 1999. Nacionalismos: el laberinto de la identidad. Madrid: Espasa-Calpe.

Delgado, L. E. 2002. La nación deseada: europeización, diferencia y la utopía de (las) España(s). In: S. Bermúdez, A. Cortijo Ocaña, \& T. McGovern, eds. From Stateless Nations to Postnational Spain/De naciones sin estado a la España postnacional. Boulder: Society of Spanish and Spanish-American Studies, pp. 207-21.

Elshtain, J.B. 1987. Women and War. New York: Basic Books.

Flesler, D. 2001. De la inmigración marroquí a la invasión mora: discursos pasados y presentes del (des)encuentro entre España y Marruecos. Arizona Journal of Hispanic Cultural Studies, 5: 73-88.

Franco, F. 30 March 2008. "Mensaje de fin de año." <http://www.generalisimofranco.com/ Discursos/ discursos/1952/00033.htm>.

Fussell, P. 1989. Wartime: Understanding and Behavior in the Second World War. New York: Oxford UP.

García de Cortázar, F. 2003. Los mitos de la historia de España. Barcelona: Planeta.

Gil Calvo, E. 2006. Máscaras masculinas: héroes, patriarcas y monstruos. Barcelona: Anagrama.

Jarvis, C. S. 2004. The Male Body at War: American Masculinity during World War II. DeKalb: Northern Illinois UP.

Juliá, S. 1999. De guerra contra el invasor a guerra fratricida. In: Víctimas de la guerra civil. Madrid: Temas de Hoy, pp. 11-54.

Linhard, T. A. 2005. Fearless Women in the Mexican Revolution and the Spanish Civil War. Columbia: University of Missouri Press.

Llorente, Á. 1995. Arte e ideología en el franquismo (1936-1951). Madrid: Visor.

Madariaga, M. R. de. 2002. Los moros que trajo Franco . . . . la intervención de tropas coloniales en la guerra civil. Barcelona: Martínez Roca.

Mayer, T. 2000. Gender Ironies of Nationalism: Setting the Stage. In: Gender Ironies of Nationalism: Sexing the Nation. London: Routledge, pp. 1-22.

Mendieta, I. R. 1938. El infierno azul. n.p.: Solidaridad.

Miquelarena, J. 1937. Cómo fui ejecutado en Madrid. Ávila: Sigirano Díaz.

Miquelarena, J. 1938. El otro mundo: la vida en las embajadas de Madrid. Burgos: Aldecoa.

Moreno, F. 1999. La represión en la posguerra. In: S. Juliá, ed. Victimas de la guerra civil. Madrid: Temas de Hoy, pp. 277-405.

Mosse, G. L. 1996. The Image of Man: The Creation of Modern Masculinity. New York: Oxford UP.

Mostov, J. 2000. Sexing the Nation/Desexing the Body: Politics of National Identity in the Former Yugoslavia. In: Tamar Mayer, ed. Gender Ironies of Nationalism: Sexing the Nation. London: Routledge, pp. 89-110.

Nagel, J. 1998. Masculinity and Nationalism: Gender and Sexuality in the Making of Nations. Ethnic and Racial Studies, 21(2): 242-69.

Núñez-Seixas, X.-M. 2005. Nations in Arms Against the Invader: On Nationalist Discourses during the Spanish Civil War. In: C. Ealham \& M. Richards, eds. The Splintering of Spain: Cultural History and the Spanish Civil War, 1936-1939. New York: CUP, pp. 45-67.

Núñez-Seixas, X.-M. 2006. ;Fuera el invasor!: nacionalismos y movilización bélica durante la guerra civil española (1936-1939). Madrid: Marcial Pons.

Orwell, G. 1938. Homage to Catalonia. London: Secker and Warburg.

Pérez Bowie, J. A. 2002. Literatura y propaganda durante la guerra civil española. In: Propaganda en guerra. Salamanca: Consorcio Salamanca, pp. 31-49.

Pomer, L. 2005. La construcción de los héroes: imaginario y nación. Buenos Aires: Leviatán.

Reig Tapia, A. 1999. Memoria de la guerra civil: los mitos de la tribu. Madrid: Alianza. 
Rodríguez-Puértolas, J. 1986. Literatura fascista española: historia. Madrid: Akal.

Said, E.W. 1978. Orientalism. New York: Vintage.

Sánchez Ruano, F. 2004. Islam y guerra civil española: moros con Franco y con la República. Madrid: La Esfera de los Libros.

Tisa, J. ed. 1979. The Palette and the Flame: Posters of the Spanish Civil War. New York: International Publishers.

Vallejo Nágera, A. 1939. La locura y la guerra: psicopatología de la guerra española. Valladolid: Santarén.

Vettel-Becker, P. 2002. Destruction and Delight: World War II Combat Photography and the Aesthetic Inscription of Masculine Identity. Men and Masculinities, 5(1): 80-102.

\begin{abstract}
non
En este artículo analizo la representación del Otro en tres textos publicados durante la guerra civil española: El infierno azul (¿1938?), del republicano Isidro R. Mendieta, y dos obras estrechamente relacionadas del falangista Jacinto Miquelarena: Cómo fui ejecutado en Madrid (1937) y El otro mundo: la vida en las embajadas de Madrid (1938). Aunque estos textos defiendan distintas ideologías políticas y sean formalmente muy diferentes, se asemejan en su constante crítica al enemigo. Concretamente, tanto los republicanos como los sublevados tienden a representar al enemigo con una masculinidad inadecuada, ya que se le describe, por un lado, como una bestia o un animal, incapaz de controlar sus instintos y, por otro, como cobarde y afeminado. De esta manera, para la construcción de la nación el Otro posee una masculinidad deficiente, o bien excesiva o bien insuficiente. Por lo tanto, las ideologías nacionalistas parecen proponer una masculinidad normativa que se sitúa en una posición ambigua difícil de establecer: una masculinidad capaz de controlar los instintos animales, pero lo suficientemente fuerte para llevar a cabo actos heroicos.
\end{abstract}

Palabras clave: Guerra Civil Española, Jacinto Miquelarena, Isidro Mendieta, masculinidades, enemigo, el Otro

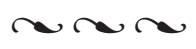

Iker González-Allende is Assistant Professor of Spanish at the University of Nebraska-Lincoln. He specializes in twentieth- and twenty-first-century Spanish literatures and cultures, with particular emphasis on gender studies and national identities. His major research interests are the Spanish Civil War, Republican exiles, and Basque narrative. He has published articles on a wide array of subjects, including the exile poetry of Ernestina de Champourcin, the memoirs of Carmen Baroja, the poetry of Concha Méndez, Falangist narrative during the Spanish Civil War, the exile experience of Ramón de Belausteguigoitia, and the exilic drama of Martín Elizondo. In 2009 he published an edition of the articles and diaries Pilar de Zubiaurre wrote before and during her thirty-year exile in Mexico. His book manuscript, Del frente a la retaguardia: género y nación en la narrativa española durante la guerra civil, analyses, from a gender and national perspective, the Spanish narrative that was written and published between 1936 and 1939.

Correspondence: Professor Iker González-Allende, University of NebraskaLincoln, Lincoln, NE 68588-0315. E-mail igonzalezallende2@unl.edu 